\title{
Analisis Sikap Konsumen Perempuan terhadap Produk Green Skincare: Pendekatan Multiatribut Fishbein
}

\author{
Nofia Ulfah Ramadhani, Berto Mulia Wibawa, dan Janti Gunawan \\ Departemen Manajemen Bisnis, Fakultas Bisnis dan Manajemen Teknologi, Institut Teknologi Sepuluh \\ Nopember (ITS) \\ e-mail: nofia.ulfah@gmail.com
}

\begin{abstract}
Abstrak-Industri perawatan kulit di Indonesia mengalami peningkatan pada beberapa tahun terakhir. Saat ini terdapat produsen penyedia skincare yang menggunakan konsep positioning ramah lingkungan, antara lain The Body Shop, Innisfree, Kiehl's, dan L'Occitane. Penelitian ini dilakukan untuk mengidentifikasi atribut yang menjadi pertimbangan konsumen dalam membeli produk green skincare. Desain penelitian yang digunakan adalah deskriptif. Pengumpulan data dilakukan menggunakan kuesioner online yang disebarkan kepada 215 sampel yang memiliki kriteria perempuan, berdomisili di Surabaya yang membeli produk green skincare dari salah satu merek penyedia green skincare yang disebutkan. Penelitian ini menemukan bahwa konsumen bersikap positif pada atribut keamanan, kinerja produk, bahan baku alami yang digunakan, kesesuaian harga dengan kualitas, bebas uji hewan, dan brand image. Maka dari itu, pemasar dari merek penyedia green skincare perlu untuk memasarkan produk skincare yang berfokus pada tingkat kepentingan atribut skincare antara lain dengan Memberikan informasi terkait alergen yang mungkin terjadi pada kemasan dan website merek penyedia skincare untuk memastikan keamanan produk pada konsumen dan bekerjasama dengan beauty vlogger untuk melakukan ulasan pada produk skincare sehingga konsumen akan lebih tertarik dalam melakukan pembelian skincare.
\end{abstract}

Kata Kunci-Atribut produk, Green skincare, Multiatribut Fishbein, Sikap Konsumen.

\section{PENDAHULUAN}

$\mathrm{P}$ ERAWATAN kulit (skincare) menjadi industri yang saat ini sedang berkembang. Pada tahun 2017, pertumbuhan industri skincare di Indonesia mencapai 6 persen dan diprediksi akan terus tumbuh seiring dengan semakin meningkatnya kepedulian wanita Indonesia dalam merawat kulit [1]. Berkembangnya industri skincare menumbuhkan inovasi keragaman produk yang digunakan dalam merawat kulit sesuai dengan kegunaannya. Kini, bagi beberapa orang, skincare tidak hanya dilakukan dengan satu langkah namun berkembang menjadi beberapa langkah dengan berbagai produk. Kebutuhan atas skincare yang meningkat menyebabkan produksi produk skincare juga meningkat.

Perusahaan yang menjadi penyedia produk skincare berpotensi melukai lingkungan karena produksi secara masal memerlukan energi yang besar, menggunakan bahan baku yang tidak mudah didaur ulang, dan menghasilkan limbah yang dapat berbahaya bagi lingkungan. Untuk mengurangi dampak lingkungan, perusahaan perlu menggunakan green marketing dalam strategi bisnis yang berkelanjutan [2]. Produksi, penyampaian kepada konsumen dan pembuangan produk dan jasa yang menggunakan green marketing dapat mengurangi kerusakan lingkungan seperti implikasi pemanasan global, limbah yang tidak mudah terurai, dan dampak berbahaya polutan [3].

Kebutuhan konsumen terbagi menjadi 5 tingkatan yaitu kebutuhan fisiologis, kebutuhan akan rasa aman, kebutuhan untuk memiliki dan kasih sayang, kebutuhan atas penghargaan dan kebutuhan untuk aktualisasi diri [4]. Skincare merupakan kebutuhan fisiologis dari konsumen. Namun, skincare yang memiliki positioning ramah lingkungan merupakan produk yang menjadi kebutuhan aktualisasi diri konsumen untuk berkontribusi mengurangi kerusakan lingkungan.

Saat ini terdapat perusahaan skincare yang telah mengusung konsep ramah lingkungan dalam menjalankan bisnis, antara lain The Body Shop, Innisfree, L'Occitane dan Kiehl's. The Body Shop merupakan perusahaan produk perawatan tubuh dan kecantikan yang memiliki visi menjadi bisnis global paling beretika dan berkelanjutan serta memiliki komitmen "Enrich Not Exploit" [5]. The Body Shop setia dalam menyajikan produk dengan bahan alami serta aktif dalam melakukan berbagai aksi dan kampanye untuk melestarikan serta melindungi sumber daya alam di bumi. Yang kedua, terdapat Innisfree yang merupakan merek penyedia produk skincare asal Korea Selatan yang memiliki komitmen terhadap lingkungan (Innisfree, 2018). Komitmen tersebut antara lain (1) mewujudkan kecantikan yang berasal dari bahan-bahan alami terpercaya, (2) mewujudkan konsumsi beretika dengan menyediakan beragam produk bermutu dengan harga bersahabat, dan (3) mempromosikan berbagai manfaat alam melalui desain ramah lingkungan. Selain itu, Kiehl's merupakan perusahaan perawatan kulit yang menyediakan produk dengan bahan alami. Kiehl's memiliki program amal melalui kerjasama dengan aliansi waterkeeper, rainforest, ecosystems dan beberapa lainnya [6]. Yang terakhir, terdapat merek L'Occitane yang menjalankan bisnisnya dengan menyediakan bahan alami berkualitas tinggi dengan bersumber secara berkelanjutan. Komitmen L'Occitane antara lain meminimalkan jejak karbon dengan membatasi penggunaan transportasi udara dan mempromosikan penggunaan energi terbarukan [7].

Dalam mengonsumsi suatu produk atau jasa, masyarakat kini semakin giat memilih merek apa yang akan digunakan. Indonesia menjadi negara berkembang nomor 1 yang memiliki permintaan produk skincare alami dan ramah lingkungan [8]. Fitur ramah lingkungan berpengaruh dalam keputusan pemilihan skincare. Penelitian terdahulu menjelaskan bahwa perilaku dan kesadaran konsumen terhadap lingkungan memengaruhi perilaku pembelian yang pro-lingkungan [9]. Penelitian ini 
penting untuk dilakukan karena peningkatan konsumsi produk skincare menjadi peluang bagi perusahaan. Namun, penyedia produk skincare yang tidak menjalankan bisnisnya secara berkelanjutan dapat berpotensi merusak lingkungan. Maka dari itu, penelitian ini dilakukan untuk mengidentifikasi atribut yang memengaruhi sikap konsumen pada produk green skincare dari merek The Body Shop, Innisfree, Kiehl's, dan L'Occitane.

\section{II.LANDASAN TEORI}

\section{A. Produk Green Skincare}

Istilah green memiliki keterkaitan dengan ramah lingkungan, tanggung jawab pada lingkungan, dan mengarah pada proses keberlanjutan [10]. Green product dikembangkan untuk mengurangi dampak lingkungan dari pengembangan, pembuatan, penggunaan, dan pembuangan produk [11]. Produk yang ditawarkan tidak terlepas dari suatu merek penyedia. Green brand adalah merek yang menawarkan produk dengan keuntungan ekologi yang signifikan dibandingkan merek lain [12]. Green brand dapat menciptakan kesan positif pada konsumen dengan memberikan atribut dan manfaat yang terkait dengan pengurangan dampak lingkungan sehingga memengaruhi kepedulian lingkungan [13].

Produk green skincare merupakan produk yang dapat membuat kulit sehat yang diolah menggunakan bahan alami yang dikombinasikan dengan agen pembawa, pengawet, surfaktan, humektan, dan pengemulsi yang terjadi secara alami [10]. Produk green skincare diproduksi secara ramah lingkungan untuk menjaga keutuhan bahan alami yang digunakan. Skincare memiliki beberapa jenis (Tabel 1).

\section{B. Theory of Reasoned Action}

Theory of Reasoned Action merupakan teori tentang niat perilaku pelanggan dimana niat seseorang menjadi suatu fungsi dari sikap orang tersebut terhadap perilaku dan norma subjektif yang dimiliki [14]. Oleh karena itu, suatu tindakan yang dilakukan konsumen dapat diprediksi dari sikap terhadap tindakan itu, asalkan ada korelasi yang tinggi antara niat dan perilaku. Sikap konsumen menggambarkan evaluasi konsumen terhadap suatu hal

Tabel 1.

Kategori Skincare

\begin{tabular}{clll}
\hline \hline Jenis Skincare & \multicolumn{3}{c}{ Produk } \\
\hline Perawatan Wajah & Cleanser & Moisturizer & Eyecare \\
& Masker & Face Mist & Exfoliator \\
& Toner & Lipcare & Makeup \\
& & & Remover \\
& Serum & Scrub & Sunscreen \\
& Day Cream & Night Cream & Face Oil \\
Perawatan Tubuh & Body Lotion & Hand Cream & Body Oil \\
& Body Butter & Footcare & Sabun Mandi \\
& Deodoran & & \\
\hline \hline
\end{tabular}

Sumber: Website Resmi The Body Shop, Innisfree, Kiehl's, dan L'Occitane (2018)

[14].

\section{Model Sikap Multiatribut Fishbein}

Analisis multiatribut merupakan analisis yang digunakan untuk mengetahui pembentukan dan perubahan sikap seseorang [15]. Sikap seseorang terhadap suatu objek atau merek dapat diketahui melalui keyakinan seseorang bahwa suatu objek terkait dengan atribut dan aspek evaluasi dari atribut tersebut [16].

\section{METODE PENELITIAN}

\section{A. Desain Penelitian}

Penelitian ini merupakan penelitian deskriptif sesuai dengan tujuan penelitian untuk mengidentifikasi sikap konsumen terhadap atribut green skincare. Data yang dibutuhkan adalah data primer mengenai demografi responden dan penilaian responden mengenai atribut green skincare yang digunakan responden.

\section{B. Sampel}

Data yang digunakan dalam penelitian ini merupakan data yang berasal dari kuesioner yang disebarkan melalui Google Formulir kepada pelanggan perempuan dari merek green skincare (The Body Shop / Innisfree / Kiehl's / L'Occitane) pada periode Mei hingga Desember 2018. Sampel dipilih menggunakan metode convenience sampling dengan jumlah minimal sampel 210 responden.

\section{Metode Analisis Data}

Analisis data dilakukan dengan menggunakan analisis multriatribut Fishbein. Analisis multiatribut Fishbein digunakan untuk mengukur sikap terhadap objek secara individu sehingga untuk menganalisis multiatribut secara keseluruhan sampel perlu dihitung kembali dengan menjumlah keseluruhan sikap responden dan membagi dengan jumlah responden. Berikut formulasi dari analisis multiatribut Fishbein:

$$
A_{o}=\sum_{i=1}^{n} b_{i} \cdot e_{i}
$$

Dimana,

$$
\begin{array}{ll}
\mathrm{A}_{\mathrm{o}} & =\text { Keseluruhan sikap seseorang terhadap suatu objek } \\
\mathrm{b}_{\mathrm{i}} & =\text { Kepercayaan individu bahwa objek memiliki atribut } \\
\mathrm{i} & \\
\mathrm{e}_{\mathrm{i}} & =\text { Aspek evaluasi individu terhadap atribut } \mathrm{i} \\
\mathrm{\Sigma} & =\text { Penjumlahan dari sejumlah atribut } \\
\mathrm{n} & =\text { Jumlah atribut }
\end{array}
$$

Pada penelitian ini, sikap yang diteliti $\left(A_{o}\right)$ adalah sikap konsumen pada produk green skincare. bi merupakan seberapa kuat konsumen percaya pada atribut yang ada pada green skincare dan ei merupakan evaluasi terhadap atribut yang terdapat pada produk green skincare. Analisis multiatribut dilakukan menggunakan skala Likert 5 poin. Tingkat kepercayaan individu memiliki kategori sangat tidak penting hingga sangat penting (1 sampai dengan 5) dan tingkat evaluasi kepercayaan memiliki kategori sangat buruk hingga sangat baik (1 sampai dengan 5).

Penentuan keseluruhan sikap seseorang terhadap suatu objek dilakukan dengan menggunakan skala interval. Skala dari kepercayaan, evaluasi, dan sikap dihitung dengan rumus sebagai berikut.

$$
\text { Skala } *=\frac{m-n}{b}
$$

Dimana,

$\mathrm{m}=$ Skor tertinggi yang mungkin terjadi

$\mathrm{n} \quad=$ Skor terendah yang mungkin terjadi

$\mathrm{b}=$ Jumlah skala penilaian yang terbentuk

*Skala sikap dihitung dengan $\mathrm{m}=\left(\mathrm{m}_{\mathrm{bi}} \mathrm{Xm}_{\mathrm{ei}}\right)$ dan $\mathrm{n}=$ $\left(\mathrm{n}_{\mathrm{bi}} \mathrm{Xn}_{\mathrm{ei}}\right)$ 


\section{D.Atribut Produk}

Atribut produk green skincare yang digunakan pada penelitian ini diadopsi dari penelitian Johti \& Sahasakmontri. Terdapat 11 atribut skincare yang diukur dalam penelitian ini meliputi atribut dasar dan atribut ramah lingkungan [17]. Atribut dasar meliputi keharuman, warna, keamanan, kinerja produk, kesesuaian harga dengan kualitas, kemasan, atmosfer toko, kesempatan untuk pretest, dan brand image sedangkan atribut ramah lingkungan meliputi bahan baku ramah lingkungan, dan bebas uji hewan (Tabel 2).

Tabel 2.

Definisi Operasional Variabel

\begin{tabular}{|c|c|c|}
\hline Kode & Atribut & Definisi \\
\hline 1 & Keharuman & $\begin{array}{l}\text { Keharuman adalah aroma alami yang timbul } \\
\text { dari skincare [18] }\end{array}$ \\
\hline 2 & Warna & $\begin{array}{l}\text { Warna berarti warna yang ada pada produk } \\
\text { skincare }\end{array}$ \\
\hline 3 & Keamanan & $\begin{array}{l}\text { Keamanan berarti produk skincare tidak } \\
\text { mengandung bahan kimia yang dapat } \\
\text { menimbulkan efek kesehatan yang buruk } \\
{[19]}\end{array}$ \\
\hline 4 & Kinerja Produk & $\begin{array}{l}\text { Kinerja produk adalah manfaat yang terjadi } \\
\text { pada kulit akibat pemakaian produk }[20]\end{array}$ \\
\hline 5 & $\begin{array}{l}\text { Kesesuaian } \\
\text { harga dengan } \\
\text { kualitas }\end{array}$ & $\begin{array}{l}\text { Kesesuaian harga dengan kualitas berarti } \\
\text { konsumen memiliki persepsi produk } \\
\text { skincare memiliki harga yang sesuai dengan } \\
\text { kualitas produk [21] }\end{array}$ \\
\hline 6 & Kemasan & $\begin{array}{l}\text { Kemasan merupakan wadah atau } \\
\text { pembungkus untuk melindungi produk } \\
\text { skincare }[21]\end{array}$ \\
\hline 7 & Atmosfer toko & $\begin{array}{l}\text { Atmosfer toko merupakan suasana yang } \\
\text { melingkupi tempat dan situasi toko skincare } \\
\text { seperti warna, music, keramaian [21] }\end{array}$ \\
\hline 8 & $\begin{array}{l}\text { Kesempatan } \\
\text { untuk pre-test }\end{array}$ & $\begin{array}{l}\text { Kesempatan untuk pre-test berarti konsumen } \\
\text { dapat mencoba produk saat berada di toko } \\
\text { Brand image adalah keakraban konsumen }\end{array}$ \\
\hline 9 & Brand image & $\begin{array}{l}\text { pada merek melalui paparan berulang dan } \\
\text { membentuk asosiasi yang kuat dengan merek } \\
{[21]}\end{array}$ \\
\hline 10 & $\begin{array}{l}\text { Bahan baku } \\
\text { ramah } \\
\text { lingkungan }\end{array}$ & $\begin{array}{l}\text { Bahan baku ramah lingkungan berarti } \\
\text { menggunakan bahan alami dan } \\
\text { dikombinasikan dengan bahan campuran } \\
\text { secara alami }[10]\end{array}$ \\
\hline 11 & $\begin{array}{l}\text { Tidak diuji } \\
\text { pada hewan }\end{array}$ & $\begin{array}{l}\text { Produk yang tidak diuji pada hewan } \\
\text { diasosiasikan sebagai produk yang tidak } \\
\text { merusak dan diasosiasikan dengan label [22] }\end{array}$ \\
\hline
\end{tabular}

\section{ANALISIS DAN DISKUSI}

\section{A. Analisis Demografi}

Target responden yang telah ditetapkan adalah sejumlah 210 responden. Setelah dilakukan pengumpulan data, terdapat total 329 responden yang mengisi kuesioner. Namun, dari 329 responden yang mengisi terdapat 215 responden $(65,3 \%)$ yang lolos screening sehingga realisasi pencapaian target responden telah sesuai dari target yang ditetapkan.

Analisis demografi dilakukan untuk mengetahui profil dari responden yang terlibat dalam penelitian ini. Responden pada penelitian ini didominasi oleh perempuan berusia 18 hingga 25 tahun (82\%), belum menikah $(87 \%)$, memiliki pekerjaan sebagai mahasiswa atau pelajar $(61 \%)$, dan memiliki rata-rata pendapatan per bulan Rp1.500.000 hingga Rp3.500.000 (36\%).

Analisis usage digunakan untuk mengetahui perilaku pembelian dan penggunaan skincare dari responden penelitian. Merek green skincare yang paling banyak digunakan responden adalah The Body Shop (53\%). Responden didominasi oleh orang memiliki jumlah skincare dari merek green skincare yang digunakan sebanyak 2 hingga 3 produk (50\%), memiliki rata-rata pengeluaran untuk setiap transaksi antara Rp250.001 hingga Rp500.000 (43\%), paling sering membeli skincare di toko offline resmi $(70 \%)$, dan memiliki preferensi tempat pembelian skincare di toko offline resmi milik merek $(73 \%)$.

\section{B. Analisis Multriatribut}

Pengolahan data dilakukan menggunakan analisis multiatribut Fishbein. Berdasarkan uji outlier yang dilakukan, terdapat 4 data yang merupakan data outlier sehingga harus dikeluarkan dari pengolahan data. Data dari 211 responden diuji reliabilitas menggunakan software SPSS 24. Uji yang dilakukan menghasilkan kekuatan kepercayaan dari 11 atribut memiliki Cronbach's Alpha sebesar 0,921 dan evaluasi kepercayaan dari 11 atribut memiliki Cronbach's Alpha sebesar 0,950.

Setelah lolos uji reliabilitas, maka uji multiatribut Fishbein dilakukan untuk mengidentifikasi sikap responden terhadap atribut yang terkait dengan skincare dengan memperhatikan kekuatan kepercayaan dan evaluasi kepercayaan. Kekuatan kepercayaan terhadap atribut dalam skincare menggambarkan seberapa penting suatu atribut perlu dimiliki oleh skincare sehingga mendorong responden untuk membeli skincare. Evaluasi kepercayaan merupakan pendapat responden mengenai seberapa baik kondisi suatu atribut pada skincare yang digunakan.

Tabel 3.

Nilai Kekuatan Kepercayaan Atribut Green Skincare

\begin{tabular}{clcc}
\hline \hline Kode & \multicolumn{1}{c}{ Atribut } & bi & Kategori \\
\hline B3 & Keamanan & 4,30 & Sangat penting \\
B4 & Kinerja Produk & 4,27 & Sangat penting \\
B5 & Kesesuaian harga dengan kualitas & 4,20 & Penting \\
B10 & Bahan Baku Alami & 4,14 & Penting \\
B11 & Bebas uji hewan & 3,95 & Penting \\
B8 & Kesempatan untuk mencoba Produk & 3,86 & Penting \\
B9 & Brand Image & 3,79 & Penting \\
B6 & Kemasan & 3,45 & Penting \\
B7 & Atmosfer Toko & 3,39 & Cukup penting \\
B1 & Keharuman & 3,17 & Cukup penting \\
B2 & Warna & 2,58 & Tidak penting \\
\hline \hline
\end{tabular}

Kekuatan kepercayaan dari 11 atribut yang dianalisis menunjukkan bahwa terdapat 2 atribut yang dirasa responden sangat penting, 6 atribut yang tergolong penting, dan 1 atribut yang tidak penting (Tabel 3). Keamanan menjadi atribut yang paling penting untuk dimiliki oleh skincare. Keamanan pada produk skincare berarti bahwa suatu produk tidak mengandung bahan kimia yang dapat menimbulkan efek kesehatan yang buruk [19]. Penggunaan skincare oleh wanita ditujukan untuk membuat kulit sehat serta menghindari dari kerusakan kulit sehingga keamanan dalam skincare menjadi hal utama yang dipertimbangkan dalam pembelian skincare. Konsumen tidak akan membeli produk yang memiliki kandungan berbahaya karena dapat bereaksi buruk di kulit. Reaksi bahan berbahaya dalam kulit tidak akan membuat kulit sehat namun akan merusak kulit.

Selain keamanan, kinerja produk juga menjadi atribut skincare yang paling penting. Kinerja produk adalah manfaat yang terjadi pada kulit akibat pemakaian produk. Konsumen membeli sebuah produk skincare untuk mencapai manfaat tertentu, terutama mencerahkan kulit, mengecilkan pori-pori, dan menghilangkan bekas jerawat [23]. Kinerja dari produk skincare yang digunakan sangat penting untuk sesuai dengan yang diinginkan konsumen. Apabila produk skincare yang digunakan tidak menghasilkan kinerja yang diharapkan, maka konsumen 
berpotensi untuk beralih pada produk skincare lain yang dapat memenuhi kebutuhan konsumen.

Atribut bahan baku alami dan bebas uji hewan termasuk dalam kategori penting. Kedua atribut tersebut memiliki kekuatan kepercayaan yang lebih rendah dibandingkan dengan keamanan, kinerja produk, dan kesesuaian harga dengan kualitas namun lebih tinggi dibandingkan kesempatan untuk mencoba produk, brand image, kemasan, dan atmosfer toko. Berbeda dengan keamanan dan kinerja produk, atribut ramah lingkungan dari skincare dinilai penting saja, tidak menjadi sangat penting atau prioritas utama dalam membeli skincare. Temuan ini menunjukkan bahwa responden memiliki kesadaran yang tinggi dalam kesehatan daripada kesadaran akan lingkungan.

Atribut yang menurut responden tidak penting adalah atribut warna. Warna skincare dapat berbeda-beda sesuai bahan baku yang digunakan. Tidak heran bila skincare dengan warna bening, putih, terang, hingga warna hitam dapat dijumpai. Warna menjadi hal yang tidak penting karena warna produk skincare tidak memengaruhi kebutuhan konsumen untuk mendapatkan manfaat dari skincare. Pada kenyataannya, skincare dengan warna gelap dan kusam yang terbuat dari kandungan vulkanik diminati oleh banyak konsumen hingga memenangkan penghargaan masker terbaik dari salah satu perusahaan media sosial kecantikan terkemuka di Indonesia bernama Female Daily.

Evaluasi kepercayaan dari 11 atribut yang dianalisis memiliki nilai pada rentang 3,67 hingga 4,09. Hal ini menunjukkan bahwa semua atribut dalam skincare yang digunakan memiliki kondisi yang baik (Tabel 4).

Tabel 4.

Nilai Evaluasi Kepercayaan Atribut Green Skincare

\begin{tabular}{clcc}
\multicolumn{4}{c}{ Nilai Evaluasi Kepercayaan Atribut Green Skincare } \\
\hline \hline Kode & \multicolumn{1}{c}{ Atribut } & ei & Kategori \\
\hline E3 & Keamanan & 4,09 & Baik \\
E9 & Brand Image & 4,03 & Baik \\
E10 & Bahan Baku Alami & 4,03 & Baik \\
E11 & Bebas uji hewan & 4,00 & Baik \\
E4 & Kinerja Produk & 3,92 & Baik \\
E7 & Atmosfer Toko & 3,88 & Baik \\
E8 & Kesempatan untuk mencoba Produk & 3,84 & Baik \\
E6 & Kemasan & 3,84 & Baik \\
E5 & Kesesuaian harga dengan kualitas & 3,78 & Baik \\
E1 & Keharuman & 3,70 & Baik \\
E2 & Warna & 3,67 & Baik \\
\hline \hline
\end{tabular}

Keamanan merupakan atribut yang memiliki nilai evaluasi paling baik diantara 10 atribut lainnya. Hal tersebut dikarenakan konsumen akan menggunakan skincare yang sesuai dengan kulitnya. Apabila suatu skincare tidak cocok dengan kondisi kulit konsumen maka konsumen akan langsung meninggalkan skincare tersebut. Atribut kedua yang memiliki nilai tinggi yaitu brand image. Konsumen memiliki pilihan yang sangat banyak atas skincare sehingga lebih selektif terhadap merek yang digunakan. Penyedia skincare yang digunakan telah memiliki brand image yang baik sehingga konsumen memiliki minat untuk membeli skincare dari penyedia tersebut. Bahan baku lingkungan dan bebas uji hewan merupakan atribut yang telah tersedia secara baik pada skincare yang digunakan responden. Hal ini berarti bahwa merek penyedia skincare yang digunakan responden telah memberikan pengetahuan terkait atribut lingkungan secara baik kepada responden.

Tabel 5.

Nilai Sikap Responden terhadap Atribut Green Skincare

\begin{tabular}{llllll}
\hline \hline Kode & Atribut & bi & ei & Ao (bi x ei) & Kategori \\
\hline
\end{tabular}

\begin{tabular}{clcccc}
\hline B3 & Keamanan & 4,30 & 4,09 & 17,58 & Positif \\
B4 & Kinerja Produk & 4,27 & 3,92 & 16,76 & Positif \\
B10 & Bahan Baku Alami & 4,14 & 4,03 & 16,67 & Positif \\
B5 & Kesesuaian harga & 4,20 & 3,78 & 15,88 & Positif \\
& dengan kualitas & & & & \\
B11 & Bebas uji hewan & 3,95 & 4,00 & 15,83 & Positif \\
B9 & Brand Image & 3,79 & 4,03 & 15,27 & Positif \\
B8 & Kesempatan untuk & 3,86 & 3,84 & 14,83 & Netral \\
& mencoba Produk & & & & \\
B6 & Kemasan & 3,45 & 3,84 & 13,23 & Netral \\
B7 & Atmosfer Toko & 3,39 & 3,88 & 13,16 & Netral \\
B1 & Keharuman & 3,17 & 3,70 & 11,72 & Netral \\
B2 & Warna & 2,58 & 3,67 & 9,47 & Negatif \\
& & & TOTAL & 160,39 & \\
\hline \hline
\end{tabular}

Data yang telah diolah menghasilkan tingkat kepentingan dan evaluasi konsumen terhadap 11 atribut yang ada. Dari nilai kepentingan dan evaluasi yang didapatkan, dapat diketahui sikap keseluruhan konsumen pada suatu atribut dalam skincare dengan menggunakan perhitungan Fishbein (Tabel 5).

Dari perhitungan yang dilakukan menunjukkan bahwa terdapat 6 atribut yang mendapatkan tanggapan positif dari responden. Dapat diketahui bahwa konsumen memiliki sikap positif terhadap keamanan, kinerja produk, bahan baku alami yang digunakan, kesesuaian harga dengan kualitas, bebas uji hewan, dan brand image. Hal ini menunjukkan bahwa konsumen memperhatikan keamanan, kinerja produk, bahan baku, kesesuaian harga dengan kualitas, bebas uji hewan, dan brand image dalam membeli suatu skincare. Selain itu, konsumen bersikap netral terhadap kesempatan untuk mencoba produk, kemasan, atmosfer toko, dan keharuman. Saat ini, pembelian skincare dapat dilakukan melalui berbagai tempat baik offline maupun online sehingga wajar apabila kesempatan mencoba produk, kemasan, dan atmosfer toko tidak menjadi perhatian utama responden dalam membeli skincare. Yang terakhir, konsumen memiliki sikap negatif atau tidak peduli pada warna dalam membeli skincare.

\section{C.Implikasi Manajerial}

Konsumen melakukan pembelian skincare tergantung dengan atribut yang sesuai dengan kebutuhan atau keinginan konsumen. Perusahaan perlu memasarkan produk yang fokus pada tingkat kepentingan atribut skincare sehingga konsumen memiliki preferensi kepada merek penyedia green skincare. Berdasarkan analisis multiatribut Fishbein, keamanan produk adalah atribut yang paling penting untuk dimiliki skincare. Bagi konsumen, keamanan utama dari skincare adalah tidak timbulnya reaksi buruk pada kulit. Hal itu berarti penyedia green skincare perlu untuk memberikan informasi terkait alergen yang mungkin terjadi. Informasi dapat disebarkan melalui kemasan maupun website merek penyedia green skincare. Selain itu, keamanan skincare juga sangat penting bagi perempuan yang sedang hamil maupun menyusui. Perempuan yang sedang hamil dan menyusui memiliki banyak pantangan dalam produk yang dikonsumsi termasuk skincare. Dengan begitu, merek penyedia green skincare perlu untuk menyediakan varian produk yang sesuai untuk konsumen dengan karakteristik tersebut. Dengan menyediakan informasi terkait kesesuaian produk dengan konsumen, konsumen akan lebih percaya untuk membeli produk skincare sehingga pangsa pasar merek penyedia skincare juga akan meningkat.

Temuan lain dalam analisis multiatribut adalah kinerja produk menjadi atribut yang termasuk sangat penting 
dalam skincare. Kinerja produk hanya dapat dirasakan oleh konsumen saat sudah menggunakan produk tersebut. Namun, saat ini konsumen banyak melakukan pencarian informasi tentang produk melalui beauty vlogger. Konsumen cenderung memiliki keinginan untuk membeli produk yang memiliki kinerja baik pada beauty vlogger yang disukai. Maka dari itu, pemasar dapat bekerjasama dengan beauty vlogger untuk melakukan ulasan pada produk skincare sehingga konsumen akan lebih tertarik dalam melakukan pembelian skincare.

\section{V.SIMPULAN DAN SARAN}

\section{A. Simpulan}

Dari 11 atribut skincare yang digunakan dalam penelitian, konsumen merespon positif pada atribut keamanan, kinerja produk, bahan baku alami, kesesuaian harga dengan kualitas, bebas uji hewan, dan brand image. Konsumen bersikap netral pada kesempatan yang diberikan merek untuk mencoba produk, kemasan produk, atmosfer toko, dan keharuman produk. Atribut yang direspon negatif oleh konsumen adalah warna karena atribut tersebut memiliki kekuatan kepercayaan yang sangat rendah.

\section{B. Saran}

Penelitian ini hanya mengambil sampel di Surabaya. Sampel ini masih bisa diperluas lagi mengingat produk green skincare telah dipasarkan diberbagai wilayah. Kemudian, atribut yang digunakan dalam mengidentifikasi sikap konsumen diadopsi dari penelitian terdahulu. Atribut tersebut didapatkan dari focus group discussion yang dilakukan di Malaysia. Pada penelitian selanjutnya, atribut dapat dilakukan penyesuaian terlebih dahulu dengan kondisi perilaku pembelian konsumen di Indonesia. Selain itu, implikasi manajerial yang dijelaskan pada penelitian ini belum divalidasi kepada merek penyedia green skincare sehingga prioritas implikasi tersebut dapat berubah sesuai dengan tujuan dari merek penyedia green skincare. Implikasi manajerial dapat divalidasi kepada merek penyedia green skincare sehingga saran yang ada dapat diimplementasikan oleh merek yang bersangkutan.

\section{DAFTAR PUSTAKA}

[1] Kontan.co.id, "Industri perawatan tubuh tumbuh 6 persen," Kontan.co.id, $2017 . \quad$ [Online]. Available: https://industri.kontan.co.id/news/industri-perawatan-tubuh-tumbuh6. [Accessed: 25-Sep-2018].

[2] K. K. Papadas, G. J. Avlonitis, and M. Carrigan, "Green marketing orientation: Conceptualization, scale development and validation," $J$ Bus. Res., vol. 80, pp. 236-246, 2017.

[3] B. D. Gondaliya, "Green marketing in India," Paripex - Indian J.
Res., vol. 3, no. 3, pp. 72-73, 2012.

[4] E. O. Aruma and M. E. Hanachor, "Abraham Maslow's hierarchy of needs and assessment of needs in community development," Int. J. Dev. Econ. Sustain., vol. 5, no. 7, pp. 15-27, 2017.

[5] The Body Shop, "What is our commitment?," The Body Shop Indonesia Website, 2018. [Online]. Available: https://www.thebodyshop.co.id/about/commitment/what-is-ourcommitment.html.

[6] Kiehls, "Kegiatan Amal," Khiels Indonesia Official Website, 2018. [Online]. Available: https://kiehls.co.id/index.php/aboutkiehls/kiehls-charity.html.

[7] L'Occitane, "Komitmen Kami," L'Occitane Indonesia Official Website, 2018. [Online]. Available: https://id.loccitane.com/engagements,41,2,86971,1088789.htm.

[8] Statista, "Green cosmetics demand by country 2016 statistic," Statista, 2018. [Online]. Available: https://www.statista.com/statistics/803595/global-demand-fornatural-organic-environmental-friendly-cosmetics/. [Accessed: 25Sep-2018].

[9] B. B. Schlegelmilch, G. M. Bohlen, and A. Diamantopoulos, "The link between green purchasing decisions and measures of environmental consciousness," Eur. J. Mark., vol. 30, no. 5, pp. 35$55,1996$.

[10] C. L. Hsu, C. Y. Chang, and C. Yansritakul, "Exploring purchase intention of green skincare products using the theory of planned behavior: Testing the moderating effects of country of origin and price sensitivity," J. Retail. Consum. Serv., vol. 34, pp. 145-152, 2017.

[11] L. Berchicci and W. Bodewes, "Bridging environmental issues with new product development.," Bus. Strateg. Environ., vol. 14, no. 5, pp. $272-285,2005$.

[12] N. M. Suki, "Green product purchase intention: Impact of green brands, attitude, and knowledge," Br. Food J., vol. 118, no. 12, pp. 2893-2910, 2016.

[13] P. Hartmann and V. Apaolaza-Ibáñez, "Green value added," Mark. Intell. Plan., vol. 24, no. 7, pp. 673-680, 2006.

[14] I. Ajzen and M. Fishbein, "Attitude-behavior relations: A theoretical analysis and review of empirical research," Psychol. Bull., vol. 84, no. 5, pp. 888-918, 1977.

[15] J. R. Bettman, N. Capon, and R. J. Lutz, "Multiattribute measurement models and multiattribute attitude theory: A test of construct validity," J. Consum. Res., vol. 1, no. 4, p. 1, 1975.

[16] M. Fishbein and I. Ajzen, Belief, Attitude, Intention, and Behavior: An introduction to theory and research. MA: Addison-Wesley, 1975.

[17] L. M. Johti and K. Sahasakmontri, "Green marketing of cosmetics and toiletries in Thailand," J. Consum. Mark., vol. 15, no. 3, pp. 265-281, 1998.

[18] Cambridge Dictionary, "Scent," Cambridge Dictionary, 2019. [Online]. Available: https://dictionary.cambridge.org/dictionary/english/scent. [Accessed: 17-Jan-2019].

[19] The Senate of the United States, Personal Care Products Safety Act. Senate and House of Representatives of the United States of America, 2017 , p. S.1113.

[20] Cambridge Dictionary, "Benefit," Cambridge Dictionary, 2019. [Online]. https://dictionary.cambridge.org/dictionary/english/benefit [Accessed: 17-Jan-2019].

[21] K. L. Keller, Strategic Brand Management, vol. 58. 2008.

[22] Peta2, "What does 'cruelty-free' really mean?," Peta2 website, 2017. [Online]. Available: https://www.peta2.com/vegan-life/whatdoes-cruelty-free-mean/. [Accessed: 17-Jan-2019].

[23] ZAP Clinic, "Zap Beauty Index," Jakarta, 2018. 